\title{
Ozone sonde cell current measurements and implications for observations of near-zero ozone concentrations in the tropical upper troposphere
}

\author{
H. Vömel ${ }^{1, *}$ and K. Diaz ${ }^{2}$ \\ ${ }^{1}$ University of Colorado, Boulder, CO, USA \\ ${ }^{2}$ National Center for Atmospheric Research, Significant Opportunities in Atmospheric Research and Science Program, \\ Boulder, CO, USA \\ *now at: Deutscher Wetterdienst, Meteorological Observatory Lindenberg, Germany
}

Received: 16 November 2009 - Published in Atmos. Meas. Tech. Discuss.: 8 December 2009

Revised: 12 April 2010 - Accepted: 21 April 2010 - Published: 29 April 2010

\begin{abstract}
Laboratory measurements of the Electrochemical Concentration Cell (ECC) ozone sonde cell current using ozone free air as well as defined amounts of ozone reveal that background current measurements during sonde preparation are neither constant as a function of time, nor constant as a function of ozone concentration. Using a background current, measured at a defined timed after exposure to high ozone may often overestimate the real background, leading to artificially low ozone concentrations in the upper tropical troposphere, and may frequently lead to operator dependent uncertainties. Based on these laboratory measurements an improved cell current to partial pressure conversion is proposed, which removes operator dependent variability in the background reading and possible artifacts in this measurement. Data from the Central Equatorial Pacific Experiment (CEPEX) have been reprocessed using the improved background treatment based on these laboratory measurements. In the reprocessed data set near-zero ozone events no longer occur. At Samoa, Fiji, Tahiti, and San Cristóbal, nearly all near-zero ozone concentrations occur in soundings with larger background currents. To a large extent, these events are no longer observed in the reprocessed data set using the improved background treatment.
\end{abstract}

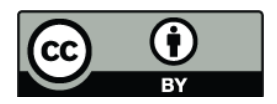

Correspondence to: $\mathrm{H}$. Vömel (holger.voemel@dwd.de)

\section{Introduction}

Ozone in the tropics has gained strong interest in recent years, driven by the need to understand the vertical distribution of ozone in this region as an indicator and driver of climate change. One of the most elusive regions has been the tropical upper troposphere, since measurements in this region are difficult to obtain and difficult to interpret. This region shows strong influx from the lower troposphere through deep convection (e.g. Kley et al., 1996), significant stratospheric influences through equatorial waves (e.g. Fujiwara et al., 1998) and midlatitude influences through intrusions from the extratropics (e.g. Waugh and Polvani, 2000). Changes in ozone concentrations in the upper tropical troposphere may contribute to temperature trends of the tropical tropopause (Randel et al., 2006) and may thus contribute to changes in stratospheric water vapor. The largest set of in situ observations comes from balloon-borne ozone sondes, which are the only instruments capable of providing both campaign based intensive measurements as well as long term observations (e.g. Thompson et al., 2003) with high vertical resolution.

The Electrochemical Concentration Cell (ECC) ozone sonde is by far the most common type of ozone sonde. This sonde type is used in numerous measurements including Kley et al. (1996) and is the instrument common to all Southern Hemispheric ADditional OZonesondes (SHADOZ) ozone sonde sites (Thompson et al., 2003). While ECC sondes generally have an absolute accuracy of 5\% (Thompson et al., 2007), the same cannot be said for the tropical troposphere (Smit et al., 2007). This region of the atmosphere generally exhibits the smallest ozone partial

Published by Copernicus Publications on behalf of the European Geosciences Union. 


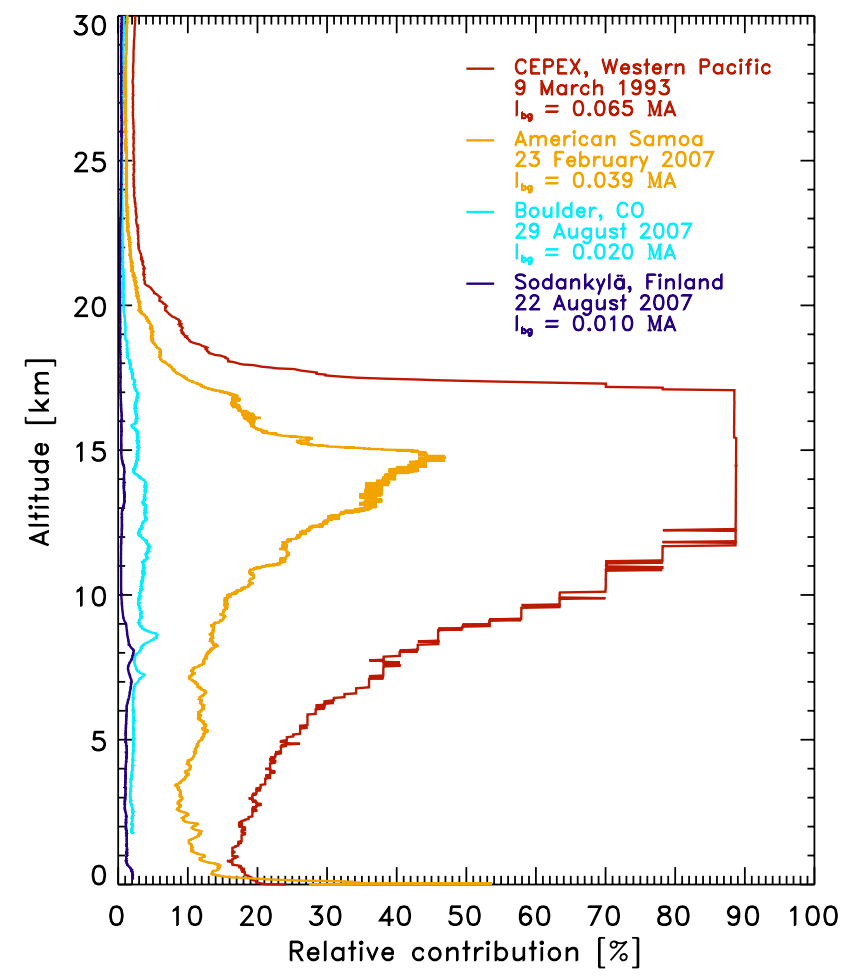

Fig. 1. Ratio of background current measured before launch to total cell current measured during flight for two tropical profiles, one typical mid latitude and one typical high latitude profile.

pressure, which means that background issues in these measurements become very important (Fig. 1). This is the case in the soundings launched during the Central Equatorial Pacific Experiment (CEPEX, Kley et al., 1996), where on average $90 \%$ of the measured signal in the ozone minimum of the upper troposphere was attributed to the sonde background and removed. Only the remaining $10 \%$ of the measured signal was assumed to result from the detected ozone. Therefore a better understanding of the sonde background current is of critical importance to the measurements in the upper tropical troposphere. Here we investigate the ECC signal at zero ozone and at known ozone concentrations in an attempt to test the appropriateness of the background measurements in the processing of ozone sonde observations. We present laboratory measurements indicating the need to reinterpret some ozone measurements in the upper tropical troposphere and the need to change the background treatment in the processing of ozone sonde measurements.

\section{Instrumentation and measurements}

\subsection{The ECC ozone sonde}

The ECC ozonesonde was originally built by Komhyr (1969) and consists of a small Teflon pump, an electrochemical cell and an electronic interface. The electrochemical cell is an iodine/iodide redox electrode and consists of two half cells containing potassium iodide (KI) solutions of different concentrations, which are connected by an ion bridge. This ion bridge allows an electrical current to flow between the two half cells while impeding mixing of the two different solutions. As air containing trace amounts of ozone is pumped through the cathode of the ECC, ozone reacts with $\mathrm{KI}$ in an aqueous solution to form iodine:

$2 \mathrm{KI}+\mathrm{O}_{3}+\mathrm{H}_{2} \mathrm{O} \rightarrow 2 \mathrm{KOH}+\mathrm{I}_{2}+\mathrm{O}_{2}$

The change in iodine concentration leads to a change in electrochemical equilibrium between the two half cells and causes 2 electrons to flow in the cells external circuit when the iodine is reconverted to iodide by the cell:

$\mathrm{I}_{2}+2 e^{-} \rightarrow 2 \mathrm{I}^{-}$

This flow of electrons through the cells external circuit can be measured and is directly proportional to the partial pressure of ozone in the sampled air (Komhyr, 1969; Johnson et al., 2002):

$P_{\mathrm{O} 3}=c T t_{100} \gamma\left(I-I_{\mathrm{bg}}\right)$

where $P_{\mathrm{O} 3}$ is in $[\mathrm{mPa}] ; I$ in $[\mu \mathrm{A}]$ is the measured cell current and $I_{\mathrm{bg}}$ is taken as the background current generated by the cell in the absence of ozone; $c=\frac{R}{\chi F}=4.309 \times 10^{-4}$ is the ratio of ideal gas constant $R$ and Faraday constant $F$ divided by the yield ratio $\chi=2$ electrons per ozone molecule; $T$ in $[\mathrm{K}]$ is the temperature of the air entering the cell, approximated by the temperature of the pump; $t_{100}$ in $[\mathrm{s}]$ is the flow rate time to pump $100 \mathrm{ml}$; and $\gamma$ is the pressure dependent pump efficiency, which corrects the reduced pump efficiency at low pressure. For laboratory measurements under normal surface pressure $\gamma$ equals 1, i.e. these measurements are performed with direct flow rate measurements and do not require a flow rate correction, which is otherwise essential in the stratospheric measurements (e.g. Torres, 1981; Johnson et al., 2002).

Several important terms contribute to the total uncertainty of the ozone partial pressure derived from the Eq. (3). Equation (3) assumes a yield ratio of 2 electrons per ozone molecule. However, secondary reactions that are not described by the basic chemistry described in Eq. (1) and Eq. (2) may change this yield ratio slightly (e.g. Davies et al., 2000). Furthermore, details of the ion bridge and the surface chemistry on the platinum electrodes may also influence this yield ratio (W. D. Komhyr, private communication, 2008). Little work has been done to study these aspects in detail and to quantify a possible deviation from $\chi=2$. The pump temperature $T$ is measured by a thermistor imbedded in the Teflon pump and is used to approximate the temperature of the airflow entering the cell. Few studies have taken place to quantify this approximation and we assume the pump temperature to be identical with the temperature of the air entering the cell (H. G. J. Smit, private communication, 2009). 
The flow rate $t_{100}$ is measured as part of the sonde preparation and is believed to be accurate to within the abilities of the observer. A good estimation of the uncertainty of $t_{100}$ is $\pm 0.1 \mathrm{~s}$ for a typical time of $28 \mathrm{~s}$. The proper pump efficiency correction is still under debate. Different research groups (Johnson et al., 2002, and references therein) have devised different methods to measure the pump efficiency correction, which do not always lead to consistent results. Differences may be as large as $10 \%$ in the upper stratosphere and clearly constitute the largest source of uncertainty for stratospheric measurements. The altitude region of interest of this paper is the upper tropical troposphere, where the pump efficiency correction is believed to be small, i.e. $\gamma \approx 1$ (Johnson et al., 2002). The accuracy of the cell current measurement is determined by the accuracy of the current meter measuring the cell current. This accuracy has not been described, but is assumed to be small. The last contribution to the total ozone partial pressure uncertainty and the focus of this paper is the background current measured as part of the sonde preparation. A new recommendation for the handling of the background current as well as a discussion of the implications will be discussed below.

Three ozonesondes were used in the experiments. One was manufactured by Science Pump Corporation (pump number 6A17552) and two were manufactured by EN-SCI (pump numbers 2Z4773 and 2Z5134). Each sonde was used in multiple laboratory runs. Furthermore, three different sensing solutions were tested: the first solution follows the recipe recommended by Komhyr (1969), which has been used in measurements by NOAA/CMDL during CEPEX and other measurements by the NOAA/ESRL/GMD (formerly NOAA/CMDL) group until 1997/98 and which is still used by other research groups. This solution uses a $1 \%$ potassium iodide (KI) solution with the addition of $25 \mathrm{~g} / \mathrm{KBr}$, buffered using $5 \mathrm{~g} / 1 \mathrm{Na}_{2} \mathrm{HPO}_{4} \bullet 12 \mathrm{H}_{2} \mathrm{O}$ and $1.25 \mathrm{~g} / 1 \mathrm{NaH}_{2} \mathrm{PO}_{4} \bullet \mathrm{H}_{2} \mathrm{O}$ and will be referred to as $1 \%$, full buffer solution. The buffer is added to the basic KI solution to maintain a constant $\mathrm{pH}$ value of the solutions, since the ozone reactions are considered to be $\mathrm{pH}$ dependent. The second solution consists of the same $\mathrm{KI}$ and $\mathrm{KBr}$ concentrations, but only 1/10th of the buffer concentration of the full buffer solution. This solution is currently being used by NOAA and several other research groups and will be referred to as $1 \%, 1 / 10$ th buffer solution. The third solution is a dilution of the original recipe by a factor of two and will be referred to as $0.5 \%$ solution. The sensing solutions were switched between the different sondes to isolate the influence of the different types of solution from that of the individual sondes.

\subsection{The ECC background}

Equation (3) assumes that for every ozone molecule entering the cell a current of two electrons per ozone molecule is generated and that a background current $I_{\mathrm{bg}}$ exists, which can be measured prior to a sounding and which is removed from the measured cell current during data processing. The background current $I_{\mathrm{bg}}$ is measured as part of the pre-launch conditioning using ozone free air at some time after the exposure with high concentrations of ozone has been switched off, although there is no clear guideline for the precise time when this reading should be taken after ozone conditioning. Common, although not universally accepted, is the cell current reading $10 \mathrm{~min}$ after the ozone conditioning. Some research groups use a cell current reading just before the high ozone conditioning as suggested by Reid et al. (1996) or a cell current reading shortly before launch.

A source of purified air is either compressed laboratory grade dry air or air that passed through activated charcoal filters (or other types of filters). While compressed laboratory grade air is the preferred method, charcoal filters are much easier to use, in particular at remote field sites. However, these filters often do not destroy ozone efficiently, in particular in high humidity environments such as the tropics. This means that when these filters are used background measurements are often overestimations due to the residual ozone present in the sampled air.

The cell background current was believed to be oxygen dependent in earlier ECC sonde versions (Saltzman and Gilbert, 1959; Komhyr, 1969, 1986) and therefore a function of altitude. Thornton and Niazy (1983) mentioned a background current decrease with pressure at less than $100 \mathrm{hPa}$. Improvements in the sonde manufacture most likely led to improvements in the cell background and particularly for low cell backgrounds $\left(I_{\mathrm{bg}}<0.1 \mu \mathrm{A}\right)$ it is no longer believed to be oxygen dependent (Komhyr et al., 1995; Thornton and Niazy, 1982, Reid et al., 1996). Variations in the cell background may, however, still occur. Komhyr et al. (1995) noted that the background may continue to decrease after it has been measured, but may also increase with exposure to the higher ozone concentrations of the stratosphere. There may also be a solution composition dependency in the background measurement (Johnson et al., 2002).

Most data processing procedures use the measured background as a constant value, although the recent Juelich Ozone Sonde Intercomparison Experiment (JOSIE, Smit et al., 2007) used a decaying background. While these variations in the background treatment are of lesser significance in typical mid and high latitude profiles, the variations are of great importance for the tropical upper troposphere.

\subsection{Measurements of the cell current using ozone free air}

The cell current of two sondes and two different solutions ( $1 \%$ full buffer and $1 \%, 1 / 10$ th buffer) was measured during and after the sonde preparation in an attempt to establish an appropriate background current $I_{\mathrm{bg}}$. In each measurement the sonde was prepared following the routine pre-launch conditioning. As part of this preparation, the sonde was exposed to the equivalent of $5 \mu \mathrm{A}$ of ozone (about $17 \mathrm{mPa}$ of 


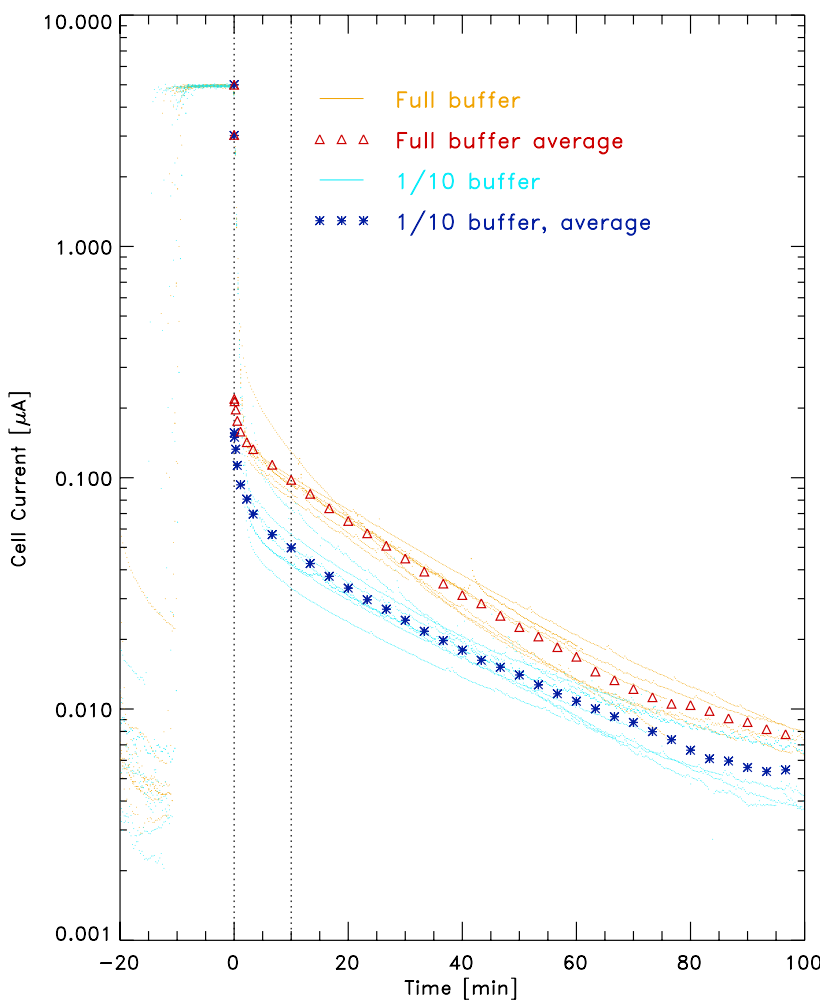

Fig. 2. Cell current with purified air before, during, and after the $5 \mu \mathrm{A}$ cell conditioning. One second data are shown for each run (thin dotted lines) as well as one minute averages over all runs using the same solution type ( $\Delta$ for full average and $*$ for $1 / 10$ th buffer solutions).

ozone partial pressure) for $10 \mathrm{~min}$, after which the air source was switched to ozone free, dry air (compressed purified air). During the entire preparation procedure and the subsequent decay the cell current was measured 3 times per second. In contrast to launch preparation procedures, the cell current measurements continued for up to $600 \mathrm{~min}$ in an attempt to establish a stable background for each solution. Figure 2 shows the cell current measurements before, during, and after the exposure to ozone. Twelve runs using the $1 \%$ full buffered solution and twelve runs using the $1 \%, 1 / 10$ th buffered solution are shown. The time is referenced to the moment when the cell current drops below $4.5 \mu \mathrm{A}$ after the air source has been switched to ozone free air. For each of the two solutions the one minute average over all runs is shown as well. In none of the runs did the cell current stabilize after the exposure with ozone and a meaningful background current could not be established.

The average reading after $10 \mathrm{~min}$ for the $1 \%$ full buffer solution is $0.1 \pm 0.01 \mu \mathrm{A}$, and for the $1 \% 1 / 10$ th buffer solution it is $0.05 \pm 0.01 \mu \mathrm{A}$. While these values are consistent with typical values reported by other groups (e.g. Smit et al., 2007), Fig. 2 clearly shows that there is no distinguishing reason to use any reading as background current $I_{\mathrm{bg}}$. Even after extensive periods of measurement (up to $10 \mathrm{~h}$ ) following ozone exposure, the cell current failed to stabilize, regardless of increasing issues with the evaporation of the solutions and very low currents. The measurements show a significant difference in the decay of the cell current between the two solutions, but not between the sondes tested. (Note that this does not imply that EnSci and Science Pump sondes are equivalent. It only implies that there is a significant difference between the two solution types).

The decay of the cell current after ozone exposure can be described to the first order by the superposition of two exponential decay functions:

$I(t)=I_{0} e^{-\frac{t}{\tau}}+I_{0}^{\prime} e^{-\frac{t}{\tau^{\prime}}}$,

where $\tau$ describes the initial fast decay and $\tau^{\prime}$ describes the subsequent slow decay. The time $t=0$ was chosen such that $I(t=0)=4.5 \mu \mathrm{A}$ to avoid the transition from constant level to exponential decay during which Eq. (4) would not hold. In these experiments the initial fast decay has a constant of $\tau=19 \mathrm{~s}$ for the $1 \%$ full buffer solution and $\tau=20 \mathrm{~s}$ for the $1 \% 1 / 10$ th buffer solution. The slow decay has a constant of $\tau^{\prime}=24 \mathrm{~min}$ and $\tau^{\prime}=28 \mathrm{~min}$ for the full buffer and $1 \% 1 / 10$ th buffer solution, respectively. The reading of the cell current after $10 \mathrm{~min}$ is found within the range of this slow decay. The slow time constants for both solutions are similar; however, the cell current at any time during the slow decay is approximately a factor of two larger for the $1 \%$ full buffer solution compared to the 1\% 1/10th buffer solution. The initial fast decay $(\tau)$ belongs to the larger contribution $I_{0}$ at $t=0$ and is due to the iodine/iodide reaction. The slow decay $\left(\tau^{\prime}\right)$ has the smaller contribution $I_{0}^{\prime}$ at $t=0$ and is believed to be due to secondary reactions, which are related to the buffer concentration, but which were not identified in detail for this study (see e.g. Davies et al., 2000; Johnson et al., 2002).

The cell current prior to the $5 \mu \mathrm{A}$ conditioning was less than $0.01 \mu \mathrm{A}$ for nearly all runs, which implies that the build up of $I_{0}^{\prime}$ during the $5 \mu \mathrm{A}$ conditioning varies between the differently buffered solutions. For the $1 \%$ full buffer solution $I_{0}^{\prime}$ reaches a larger value at the end of the $5 \mu \mathrm{A}$ conditioning compared to the $1 \% 1 / 10$ th buffer solution. This implies that the $1 \%$ full buffer solution is overestimating the amount of ozone and consequently this overestimation is to some extent dependent to the exposure to ozone (see discussions below).

\subsection{Measurements of the cell current at defined ozone concentrations}

Since the suitability of the standard background measurement could not be established in purified air, the cell current background $I_{\mathrm{bg}}$ was measured at defined ozone concentrations. The same procedure as in Sect. 2.3 was used for the initial ozonesonde preparation and for the $5 \mu \mathrm{A}$ conditioning at the beginning of each experiment. After ozone conditioning the air source was switched to purified air to allow the cell current to decay for about five minutes. The air source 

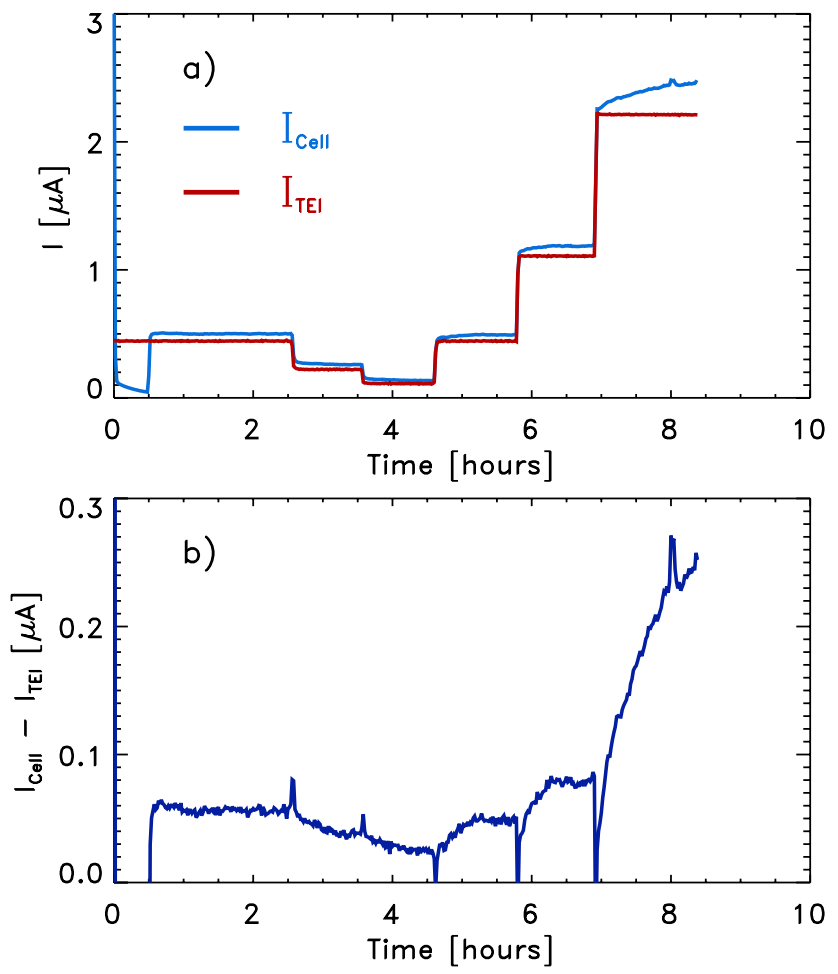

Fig. 3. Example of progression of ozone levels. (a) Measured cell current $I_{\text {cell }}$ and expected cell current $I_{\text {TEI }}$. (b) Difference of measured and expected cell current.

was then switched to air coming from an ozone calibrator (model TEI 49C). Ozone concentrations in the air coming from the calibrator were selected at 5, 10, 20, 40, 50, 80, and $100 \mathrm{ppbv}$. During these experiments cell current, pump temperature, ambient pressure and ozone mixing ratio in the air coming from the calibrator were recorded continuously. The pump flow rate was repeatedly measured to verify its stability. The mixing ratio in the air from the ozone calibrator was converted to a corresponding cell current $\left(I_{\mathrm{TEI}}\right)$ using the measured parameters in Eq. (3). Note that the pump efficiency correction is equal to one since this work was done at surface pressures.

Figure 3a shows as example the measured cell current using the $1 \%$ full buffer solution and the expected cell current $I_{\mathrm{TEI}}$ based on the calibrator output of a run using the full buffer solution. Similar to Fig. 2 the time $t=0$ was chosen when the cell current dropped below $4.5 \mu \mathrm{A}$ immediately following the $5 \mu \mathrm{A}$ conditioning. This measurement was repeated using three different sondes as well as using three different solutions for a total of 22 runs. In all runs the ozone mixing ratio was held constant for between one and a half and two hours to reduce the impact of decay and other time lag issues. The mean difference between the measured and the expected cell current was taken as the average of each mixing ratio plateau.

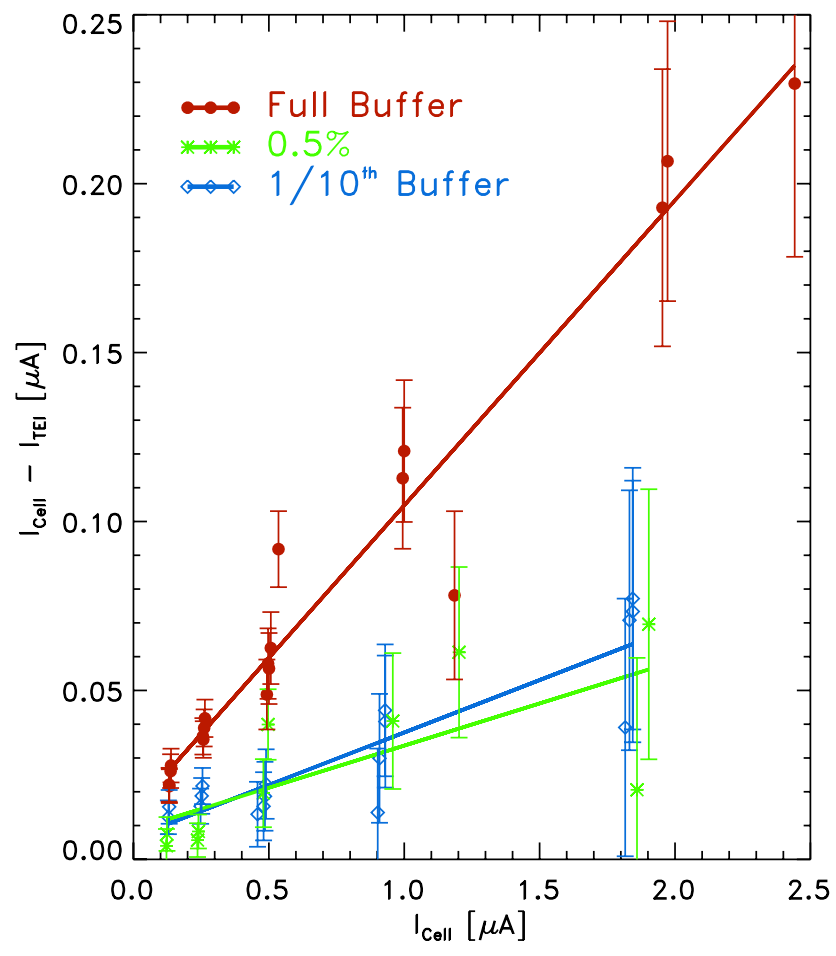

Fig. 4. Excess cell current as function of measured cell current and solution recipe.

Figure 3a indicates that the difference after more than $6 \mathrm{~h}$ (i.e. exceeding the time of a typical ozone sounding by about a factor of two) begins to increase non-systematically. This is most likely a result of the evaporation of sensing solutions. The runs were therefore limited to less than $5 \mathrm{~h}$ to avoid evaporation related artifacts.

Figure $3 \mathrm{~b}$ shows the difference between the measured and expected cell current shown in Fig. 3a. If a constant background $I_{\mathrm{bg}}$ existed, it would be easily determined from this difference. No such constant background was found. The difference between measured cell current and expected cell current clearly depends on the amount of ozone flowing through the cell as noted by Komhyr et al. (1995).

\section{Discussion}

In Sect. 2.2 it was discussed that a constant background in the absence of ozone cannot be determined, because the cell current continues to decay with time. In Sect. 2.3 it was discussed that a constant background independent of the ozone concentration cannot be determined, since the background measurement under ozone exposure is directly correlated to the ozone concentration. Therefore, it must be concluded that the concept of a constant background must be treated with caution and that Eq. (3), which relates the cell current to the ozone partial pressure, needs to be modified. 
Figure 4 shows the mean difference between the measured cell current and the expected cell current based on the calibrator ozone mixing ratio as a function of the measured cell current (i.e. ozone partial pressure). A total of 46 constant mixing ratio plateaus were analyzed within the 22 runs performed. Although the total uncertainty in these measurements considers the uncertainties in flow rate, pump temperature, air pressure and cell current measurement, the error bars shown in Fig. 4 are largely determined by the accuracy of the ozone concentration of the calibrator output. Even though the calibrator is believed to be accurate to within $1 \%$, this uncertainty becomes dominant in the comparison of the measured and expected cell current.

For all three solutions the response to ozone is larger than expected and the excess response is larger for the $1 \%$ full buffer solution compared to the $1 \% 1 / 10$ th buffer solution and the $0.5 \%$ solution. This result is consistent with previous studies, which have reported that an increase in buffer concentration increases the ozone response of the ECC (Komhyr 1995; Johnson et al., 2002; Davies et al., 2000; Tarasick et al., 2005).

The excess ozone response can be expressed as a function of measured cell current for each of the tested solutions as

$$
I_{\text {cell }}-I_{\mathrm{TEI}}=\alpha I_{\text {cell }}+\beta
$$

where $\alpha=0.090 \pm 0.005$ and $\beta=0.014 \pm 0.005 \mu \mathrm{A}$ for the full buffer solution, $\alpha=0.031 \pm 0.004$ and $\beta=0.007 \pm 0.004 \mu \mathrm{A}$ for the 1/10th buffer solution, and $\alpha=0.024 \pm 0.009$ and $\beta=0.009 \pm 0.009 \mu \mathrm{A}$ for the $0.5 \%$ solution. The slope parameter $\alpha$ implies that the full buffer solution overestimates the amount of ozone by $9 \%$, the 1/10th buffer solution overestimates the ozone amount by only $3.1 \%$, and the $0.5 \%$ solution overestimates the ozone amount by $2.4 \%$. The correlations are statistically significant as well as the difference between $1 \%$ full buffer solution and the other two solutions, whereas the difference between the $0.5 \%$ and the $1 \%, 1 / 10 \%$ buffer solution is not significant.

The overestimation shown in Fig. 4 and described in Eq. (5) can be used to modify Eq. (3) into a more appropriate form:

$$
P_{\mathrm{O} 3}=c T t_{100} \gamma((1-\alpha) I-\beta)
$$

In this modified equation, the additional term $(1-\alpha)$ implies that the reactions of ozone create more than 2 electrons per molecule of ozone, which is consistent with other studies (e.g. Komhyr et al., 1995). The fact that this factor is dependent on the buffer concentration indicates that a reaction with the buffer components is at least in part responsible for the excess signal. The constant term $\beta$ is the modified background current. This modified background can only be measured in the presence of ozone and only if the stoichiometry (i.e. the factor $\alpha$ ) is properly known. For all three solutions this new constant term is significantly lower than the cell current measured as background $10 \mathrm{~min}$ after ozone conditioning and clearly indicates that a background reading $10 \mathrm{~min}$ after the ozone conditioning is inappropriate. However, this constant term can not be measured in ozone free air.

A decay of the cell current after ozone sonde preparation and the dependency of the ozone measurement on the sonde sensing solution as shown in this study has been reported by a number of previous studies (e.g. Davies et al., 2000) and the measurements presented here are likely applicable to all ozone sonde data, which use either the $6 \mathrm{~A}$ or $2 \mathrm{Z}$ sonde type and use either the $1 \%$ full buffer solution, the $1 \%, 1 / 10$ th buffer solution or the $0.5 \%$ solution.

The cell current at $10 \mathrm{~min}$ after exposure is comparable to typical background currents reported by Smit et al. (2007) and the results presented here are comparable to typical ozone sonde observations. This suggests that the pre-launch background reading is generally an overestimate of the modified background and that this background reading causes artificially low ozone values, in particular at low cell currents. For typical mid and high latitude soundings this low bias is lesser significant, but it does play a very significant role in the tropical upper troposphere (Fig. 1). This low bias would also impact soundings over Antarctica during the ozone hole season, when nearly all of the ozone in region $12-20 \mathrm{~km}$ has been destroyed. Observations in the boundary layer are less impacted due to the higher partial pressure of ozone.

\section{Application to atmospheric observations}

\subsection{Ozone observations during CEPEX}

In March 1993 twenty five ozonesondes were successfully launched in the tropical central Pacific between Solomon Islands and Christmas Island as part of the Central Equatorial Pacific Experiment (CEPEX). Seven of these soundings showed near-zero ozone concentrations with values of less than $5 \mathrm{ppbv}$ in the upper troposphere along $2^{\circ} \mathrm{S}$ (Kley et al., 1996). Possible explanations for these low values were chemical destruction of ozone in the upper troposphere due to unidentified reactions or undiluted vertical transport of air from the boundary layer to the upper troposphere through deep convection. Modeling studies, however, were unable to reproduce the extremely low ozone concentrations observed in these soundings (e.g. Lawrence et al., 1999).

The background current measurements during this campaign were taken within minutes after ozone conditioning. The processing of the ozone observations using these measurements was certainly incorrect, since it led to negative ozone concentrations in many of the soundings, meaning the background current used in Eq. (3) was larger than the measured cell current. The background current used in the final processing was subsequently based on previous studies and a value of $0.065 \mu \mathrm{A}$ was used for all soundings. This value is consistent with those obtained in other laboratory experiments (JOSIE 1996-2000 (Smit et al., 2007) measured background currents between $0.05 \mu \mathrm{A}$ and $0.11 \mu \mathrm{A}$ ) and it is 


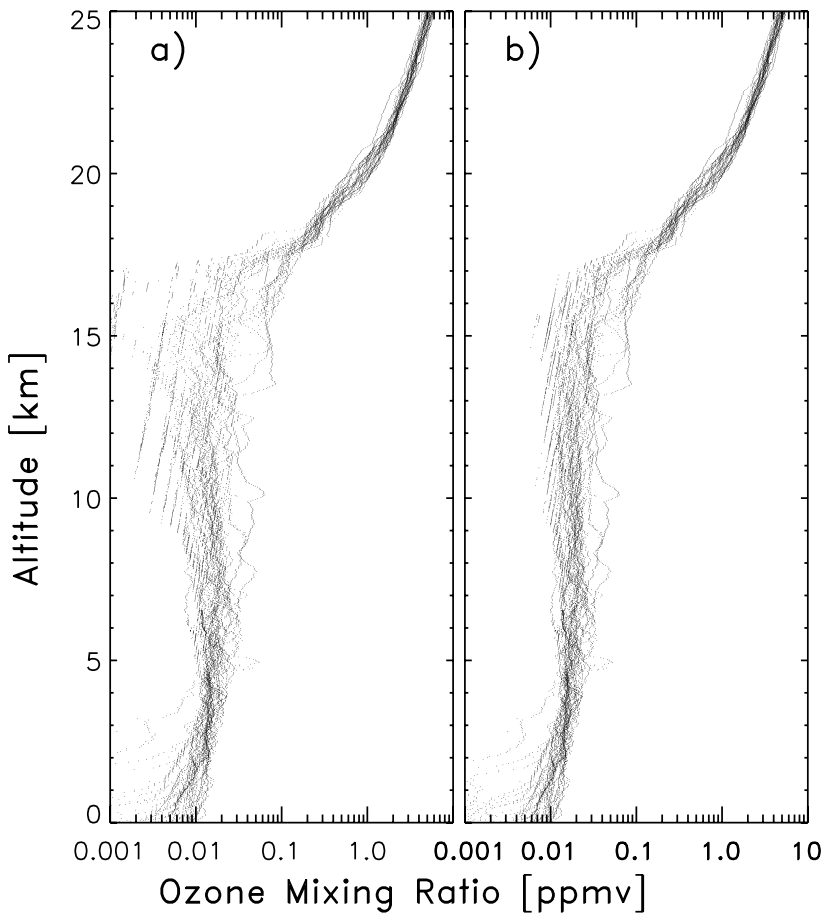

Fig. 5. (a) CEPEX ozone profiles using original background value; (b) reprocessed CEPEX ozone profiles.

consistent with the readings obtained in the zero-air measurements presented above. However, this value constitutes on average $90 \%$ of the measured cell current minimum for the Western Pacific CEPEX profiles (Fig. 1) and exceeds the lowest measured cell currents in a number of the soundings. Hence, the derived ozone concentration largely depends on the suitability of the background current that was used in the processing.

As discussed above, the pre-launch background measurement is likely erroneous and can lead to an overcorrection of the ozone measurements in particular under conditions comparable to CEPEX. Therefore, CEPEX data were reprocessed disregarding the original background value and instead using Eq. (6) with the regression parameters for the $1 \%$ full buffer solution. Figure 5 shows all original and all reprocessed profiles. As expected the largest impact on the profiles is in the upper troposphere, where the cell current is smallest. The reprocessed profiles no longer show near-zero ozone concentrations in this region, rather the ozone profiles throughout most of the troposphere show a nearly constant profile with values between $13 \mathrm{ppbv}$ and $28 \mathrm{ppbv}$ at $5 \mathrm{~km}$ and between 8 ppbv and 73 ppbv at $15 \mathrm{~km}$. Given the uncertainties in the modified background treatment (i.e. uncertainties of the intercept $\beta$ in Eq. 6), the lowest mixing ratios found in the upper troposphere are no longer significantly different from the mixing ratios found in the lower troposphere above the boundary layer. Therefore, the low ozone concentrations in the upper troposphere can easily be explained by verti- cal transport of ozone poor air from the lower and middle troposphere through deep convection. Justifications, such as undiluted vertical transport of air from the boundary layer, or a chemical destruction mechanisms for ozone are no longer necessary to explain these upper tropospheric observations.

The CEPEX soundings were executed using model 5A ozone sondes, which were not evaluated here. Thus, some questions remain, whether the results shown here are also applicable to this ozone sonde type and to the CEPEX measurements.

Reid et al. (1996) used model 5A ozone sondes and the $1 \%$ full buffer solution in a comparison with a reference ozone analyzer. Their measurements document background measurements prior to cell conditioning $\left(I_{\mathrm{bg} 1}=0.05 \mu \mathrm{A}\right)$, after ozone conditioning $\left(I_{\mathrm{bg} 2}^{*}=0.1 \mu \mathrm{A}\right)$, and before launch $\left(I_{\mathrm{bg} 2}^{*}=0.01 \mu \mathrm{A}\right)$. These measurements are comparable to the measurements shown in Fig. 2 and represent the decay of the background current shown in Fig. 2. These laboratory measurements indicate that model 5A and model 6A sonde behave similarly with respect to the cell current measurement in ozone free air.

South Pole soundings during October 1992 and 1993, i.e. during the ozone hole season, also used model $5 \mathrm{~A}$ sondes and the full buffered solution. Ozone destruction in the $15-20 \mathrm{~km}$ region can be nearly complete during this month (e.g. Hofmann et al., 1994) and ozone concentrations in this altitude range frequently reach near-zero concentrations. Therefore, these observations are equivalent to the CEPEX observations in terms of instrumentation, as well as in the range of pressures, temperatures, and ozone concentrations; and can be used to estimate the background current for model 5A sondes from in situ measurements.

Figure 6 shows the altitude profiles of ECC cell current for these South Pole soundings as well the CEPEX soundings. The cell current minima measured in the $14-18 \mathrm{~km}$ layer fall between $0.027 \mu \mathrm{A}$ and $0.113 \mu \mathrm{A}$ for the 12 South Pole soundings and between $0.029 \mu \mathrm{A}$ and $0.152 \mu \mathrm{A}$ for the 27 CEPEX soundings. In $75 \%$ of the South Pole soundings (9 out of 12) the cell current minimum is less than $0.065 \mu \mathrm{A}$ (the value used as background in CEPEX), but only in $26 \%$ of the CEPEX soundings (7 out of 27). At South Pole the lowest values are obtained in the core of the ozone hole and are assumed to correspond to ozone free air. Therefore, these cell current minima are an upper limit for the background current that these 5A sondes exhibited. The sondes at South Pole also passed through higher ozone concentrations in the troposphere and a layer of significant ozone concentrations between $8 \mathrm{~km}$ and $13 \mathrm{~km}$. The slow decay of the secondary reaction after this exposure likely contributes to the measured signal in the $15-20 \mathrm{~km}$ layer, in contrast to the tropical soundings, where this ozone maximum is absent and where the cell current nearly monotonically decreases between the lower troposphere and the upper troposphere. Thus, the cell current minima in the $15-20 \mathrm{~km}$ region at South Pole are expected to 


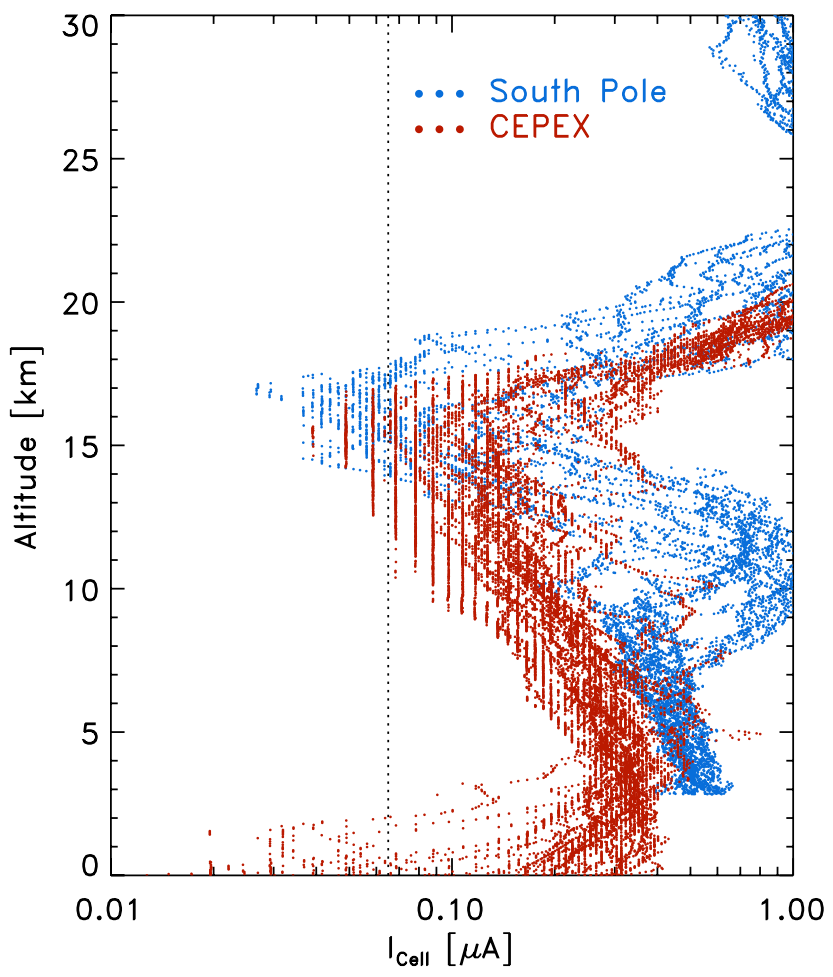

Fig. 6. Model 5A sonde cell current profiles for October 1992 and October 1993 soundings at South Pole in blue and for CEPEX soundings in red. The background current used for the CEPEX observations $(0.065 \mu \mathrm{A})$ is shown for reference as vertical dotted line.

be larger than the proper background for the tropical soundings. The South Pole cell current minima are quite low already and the corresponding tropical cell current background should be even lower. Furthermore, the South Pole cell current minima are significantly lower than the background current that was used in the original CEPEX processing. In addition, $44 \%$ of the CEPEX sondes showed cell currents in the boundary layer lower than $0.065 \mu \mathrm{A}$ and some as low as $0.01 \mu \mathrm{A}$, which is another indication that the CEPEX background values were inappropriate.

Therefore, the comparison with South Pole profiles during the ozone hole season and the analysis of the cell current profiles clearly indicate that the background current applied during CEPEX was too large and support the conclusion that the analysis based on $6 \mathrm{~A}$ and $2 \mathrm{Z}$ sondes can be applied as well to the 5A sondes used in CEPEX.

\subsection{Other tropical ozone observations}

Near-zero ozone observations have been reported at other locations as well. Solomon et al. (2005), for example, reported near-zero ozone events at Samoa, Tahiti, San Cristobal, Galapagos, and Ascension Island. The largest number of nearzero ozone events was found at Samoa with minimum ozone concentrations of less than 1 ppbv. At Samoa 43 out of 466

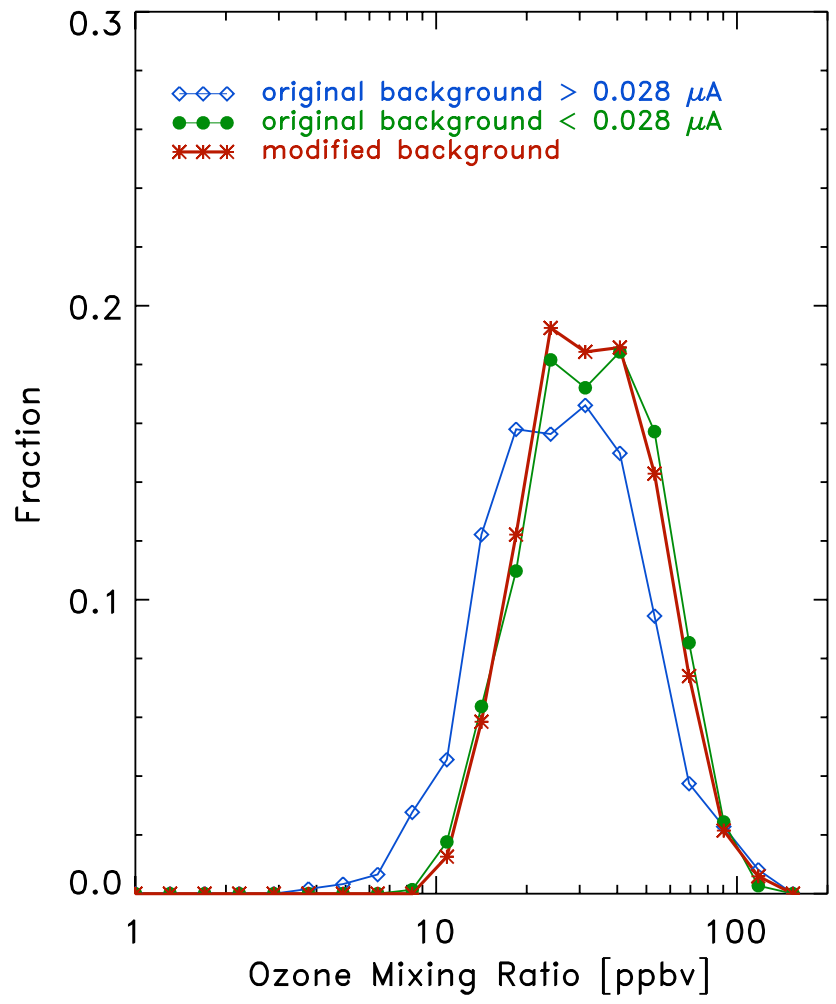

Fig. 7. Distribution of ozone observations at $200 \mathrm{hPa}$ at Fiji, San Cristobal, Samoa, and Tahiti for all soundings between 1995 and 2008. Original data that used background currents larger than $0.028 \mu \mathrm{A}$ shown in blue diamonds (779 soundings), original data that used background currents less than $0.028 \mu \mathrm{A}$ shown in green dots (621 soundings). Shown in red stars are all data reprocessed using the modified background, disregarding the measured background current.

soundings show ozone minima below $10 \mathrm{ppbv}$ in the upper troposphere, at Fiji 26 out of 317, at Tahiti 16 out of 166 and at Galapagos 7 out of 364 .

Figure 7 shows the occurrence distribution of the ozone concentration at $200 \mathrm{hPa}$ at Fiji, Galapagos, Samoa, and Tahiti. The original data were grouped by the background current that was used in processing. and a distribution was calculated for all soundings using a low background current and a higher background current. Out of all soundings at these stations, 779 soundings (green curve, solid dots) used a background current of less than $0.028 \mu \mathrm{A}$ (twice the value of the parameter $\beta$ in Eq. 6), while 621 soundings (blue curve, diamonds) used a background current larger than this value. Although there is no particular pattern in when or where higher background currents were measured, nearly all events with less than $10 \mathrm{ppbv}$ of ozone were observed in soundings that used a higher background current, indicating the same artifact contributing to near-zero ozone concentrations as found during CEPEX. In fact, the lowest ozone mixing ratios at these stations were observed at 
background currents exceeding the background current used for the CEPEX data. All soundings at these stations were reanalyzed using Eq. (6) instead of the originally measured background current with the corresponding modified coefficients for the $1 \%$ full buffer solution and using the coefficients for the $1 \%, 1 / 10$ th buffered solution in place of the $2 \%$ unbuffered solution, which was not investigated. The reprocessed distribution of ozone at $200 \mathrm{hPa}$ (Fig. 7, red curve, stars) is nearly identical to the original distribution for soundings with low background currents and shows almost no near-zero ozone events. Therefore, the distribution of ozone concentration measured with higher background currents may be brought into agreement with the distribution of ozone measured with lower background currents if the originally used background current is disregarded and the modified background treatment is used instead. Performing this task removes nearly all of the near-zero ozone events and indicates once more that these near-zero ozone events may be a result of the large (incorrect) background currents that were used in processing.

Interestingly, at Galapagos only 3 out of 7 soundings with near-zero ozone concentrations were removed although the magnitude of the ozone minimum increased for all soundings. In at least one of the remaining four profiles a volcanic influence from Tunguragua volcano in mainland Ecuador is suspected to cause artificially low readings through the interference of $\mathrm{SO}_{2}$ with the cell chemistry (Komhyr, 1969). Due to the frequent activity of Tungurahua and other volcanoes in South America there is a possibility that $\mathrm{SO}_{2}$ interference may have affected more than one sounding at Galapagos, although without a more detailed analysis these cases will be difficult to identify.

A sounding at Samoa on 13 March 1998 shows a very broad layer between $13.7 \mathrm{~km}$ and $15.7 \mathrm{~km}$ where the cell current mostly equals to zero. This is an atypical behavior for an ozone sonde; however, since the electronics of the ECC is unable to measure negative currents, it can be suspected that the actual current generated by the cell was less than 0 , caused by an unidentified interference.

\section{Summary and final remarks}

Laboratory measurements of the ECC cell current after the standard $5 \mu \mathrm{A}$ conditioning using ozone free air revealed that a constant background current, which can be measured under laboratory conditions, could not be established. Due to the continuously decaying cell current, pre-flight measurements of the background current depend on the timing of the cell current reading after the $5 \mu \mathrm{A}$ conditioning, which introduces an operator dependent variability. In addition the measurement of the cell current after the $5 \mu \mathrm{A}$ conditioning depends on the quality of the ozone free air source. Commonly used activated charcoal filters often do not sufficiently filter ozone under high humidity conditions typically found in tropical regions and may create an artificially high zeroozone cell current. At very low ozone partial pressures (very low cell currents), which are found in the upper tropical troposphere and in the Antarctic ozone hole, the derived ozone mixing ratio is extremely sensitive to the background current used in the analysis. Pre-flight measured background currents frequently lead to apparent near-zero ozone observations, which need to be considered a measurement artifact. Therefore, pre-flight measurements of the background cell current should not be used in the processing of ECC ozone sonde data and should only be used to verify the proper operation of the ozone sondes.

Measurements of the cell current using well defined ozone concentrations show that the stoichiometry of the cell chemistry has not been fully described and that more than 2 electrons per ozone molecule are generated, which leads to an overestimation of the ozone amount as many other studies have mentioned (e.g. Komhyr et al., 1995; Johnson et al., 2002). The extrapolation of this correlation to ozone free air allows a better interpretation of the cell current under very low ozone amounts as well as a more appropriate analysis at larger ozone concentrations. Instead of a measured background current, Eq. (6) should be used to process ozone sonde data, using the appropriate solution dependent coefficients.

Reprocessing of tropical data, in particular of the CEPEX data, substituting the originally used background current with the parameters used in Eq. (6) removes most near-zero ozone observations in the tropical upper troposphere (all such observations in case of the CEPEX data). An additional process for chemical removal of ozone in the upper troposphere appears no longer to be necessary and all of the low ozone events in this region can be explained by vertical mixing of the free troposphere through deep convection, possibly followed by long range transport.

The fact that most artificial near-zero ozone events appeared in the western to south western tropical Pacific is related to the fact that the lowest mixing ratios (i.e. cell currents) occur in this region, which is a reflection of the tropospheric wave-one distribution of ozone (Thompson et al., 2003), and that these observations show the strongest sensitivity to the modified background treatment. Due to this sensitivity and the variations and changes in procedure and in solutions, trend analyses for tropical upper tropospheric ozone based on ozone sondes need to be evaluated with great care.

Reid et al. (1996) had conducted a similar study, but concluded that the intermediate pre-conditioning reading of the background current is most appropriate. However, they did not consider the overestimation of the $1 \%$ full buffer solution. Instead, they attributed the overestimation of ozone to the lower background value and not to the incomplete stoichiometry using the $1 \%$ full buffer solution.

The analysis undertaken here may be repeated with the data set obtained during the JOSIE campaigns to improve 
the statistics and to extend these data to observations under lower pressures and other solution recipes. The JOSIE data should also allow a better separation of the different factors contributing to the total ozone partial pressure uncertainty. However, in a reanalysis of JOSIE data, the measured background currents should not be used as such. Instead the modified background as discussed here might also be extracted from the JOSIE measurements to confirm our results.

The laboratory measurements presented here have focused on the steady state response of the ECC sonde to ozone in order to separate the time dependent ozone response from a constant modified background. We have used the laboratory results to suggest a better treatment of the time invariant contribution to the sensor signal; however; we have also quantified some of the time constants involved in the time variant ozone dependent sensor signal. For an improved ECC data processing the time constants need to be considered, along with a better understanding of the pump efficiency and the reaction stoichiometry.

The study presented here did not investigate any variability among instruments, nor any systematic differences between the different ECC sonde models (6A from Science Pump and $2 \mathrm{Z}$ from EnSci). The difference between the different sondes investigated here was smaller than the differences introduced by the different solution types. Furthermore, the procedure and operator dependent treatment of the background introduces a far larger uncertainty for tropical upper tropospheric ozone measurements than instrument to instrument variability might produce. Also, instrument to instrument variabilities of the background current can not be studied if the concept of a constant background for any individual sonde is inappropriate. Therefore a proper background treatment as suggested in this study will be an important step to improving ozone sonde measurements in the tropical upper troposphere.

Acknowledgements. The authors would like to thank Rajul Panda of the NCAR SOARS program for his support as well as Bryan Johnson and Sam Oltmans for fruitful discussions and support in taking these measurements. Thanks to Rigel Kivi for supplying the ozone sonde profile at Sodankylä.

Edited by: J.-P. Pommereau

\section{References}

Davies, J., Tarasick, D. W., McElroy, C. T., Kerr, J. B., Fogal, P. F., and Savastiouk, V.: Evaluation of ECC Ozonesonde Preparation Methods from Laboratory Tests and Field Comparisons during MANTRA, Proceedings of the Quadrennial Ozone Symposium Sapporo, Japan, 2000, edited by: Bojkov, R. D. and Kazuo, S., pp. 137-138, 2000.

Fujiwara, M., Kita, K., and Ogawa, T.: Stratosphere-troposphere exchange of ozone associated with the equatorial Kelvin wave as observed with ozonesondes and rawinsondes, J. Geophys. Res., 103, 19173-19182, 1998.
Hofmann, D. J., Oltmans, S. J., Lathrop, J. A., Harris, J. M., and Vömel, H.: Record low Ozone at South Pole in the Spring of 1993, Geophys. Res. Lett., 21, 421-424, 1994.

Johnson, B. J., Oltmans, S. J., Vömel, H., Smit, H. G. J., Deshler, T., and Kröger, C.: Electrochemical concentration cell (ECC) ozonesonde pump efficiency measurements and tests on the sensitivity to ozone of buffered and unbuffered ECC sensor cathode solutions, J. Geophys. Res., 107, 4393, doi:10.1029/2001JD000557, 2002.

Kley, D., Crutzen, P. J., Smit, H. G. J., Vömel, H., Oltmans, S. J., Grassl, H., and Ramanathan, V.: Observations of near-zero ozone concentrations over the convective pacific: effects on air chemistry, Science, 274, 230-233, 1996.

Komhyr, W. D.: Electrochemical concentration cells for gas analysis, Annales de Geophysique, 25, 203-210, 1969.

Komhyr, W. D.: Operations handbook-Ozone measurements to 40$\mathrm{km}$ altitude with model $4 \mathrm{~A}$ electrochemical concentration cell (ECC) ozonesondes (used with $1680 \mathrm{MHz}$ radiosondes), NOAA Tech. Memo. ERL ARL-149, Air Resources Laboratory, Boulder, CO, 1986.

Komhyr, W. D., Barnes, R. A., Brothers, G. B., Lathrop, J. A., and Opperman, D. P.: Electrochemical concentration cell ozonesonde performance evaluation during STOIC 1989, J. Geophys. Res., 100, 9231-9244, 1995.

Lawrence, M. G., Crutzen, P. J., and Rasch, P. J.: Analysis of the CEPEX ozone data using a 3D chemistry-meteorology model, Q. J. Roy. Meteorol. Soc., 125, 2987-3009, 1999.

Randel, W. J., Wu, F., Vömel, H., Nedoluha, G. E., and Forster, P.: Decreases in stratospheric water vapor after 2001: Links to changes in the tropical tropopause and the Brewer-Dobson circulation, J. Geophys. Res., 111, D12312, doi:10.1029/2005JD006744, 2006.

Reid, S. J., Vaughan, G., Marsh, A. R. W., and Smit, H. G. J.: Accuracy of ozonesonde measurements in the troposphere, J. Atmos. Chem., 25, 215-226, 1996.

Saltzman B. E. and Gilbert, N.: Iodometric Microdetermination of Organic Oxidants and Ozone. Resolution of Mixtures by Kinetic Colorimetry, Anal. Chem., 31, 1914-1920, 1959.

Smit, H. G. J., Strater, W., Johnson, B. J., et al.: Assessment of the performance of ECC-ozonesondes under quasi-flight conditions in the environmental simulation chamber: Insights from the Juelich Ozone Sonde Intercomparison Experiment (JOSIE), J. Geophys. Res., 112, D19306, doi:10.1029/2006JD007308, 2007.

Solomon, S., Thompson, D. W. J., Portmann, R. W., Oltmans, S. J., and Thompson, A. M.: On the distribution and variability of ozone in the tropical upper troposphere: Implications for tropical deep convection and chemical-dynamical coupling, Geophys. Res. Lett., 32, L23813, doi:10.1029/2005GL024323, 2005.

Thompson, A. M., Witte, J. C., McPeters, R. D., Oltmans, S. J., Schmidlin, F. J., Logan, J. A., Fujiwara, M., Kirchhoff, V. W. J. H., Posny, F., Coetzee, G. J. R., Hoegger, B., Kawakami, S., Ogawa, T., Johnson, B. J., Vömel, H., and Labow, G.: The 19982000 SHADOZ (Southern Hemispheric Additional Ozonesondes) tropical ozone climatology: Comparison with TOMS and groundbased measurements, J. Geophys. Res., 108(D2), 8238, doi:10.1029/2001JD000967, 2003.

Thompson, A. M., Witte, J. C., Smit, H. G. J., Oltmans, S. J., Johnson, B. J., Kirchhoff, V. W. J. H., and Schmidlin, F. J.: Southern Hemisphere Additional Ozonesondes (SHADOZ) 1998-2004 
tropical ozone climatology: 3. Instrumentation, station-to-station variability, and evaluation with simulated flight profiles, J. Geophys. Res., 112, D03304, doi:10.1029/2005JD007042, 2007.

Thornton, D. C. and Niazy, N.: Sources of background current in the ECC ozonesonde: Implications for total ozone measurements, J. Geophys. Res., 87, 8943-8950, 1982.

Thornton, D. C. and Niazy, N.: Effects of solution mass transport on the ECC ozonesonde background current, J. Geophys. Res., 10, 148-151, 1983.
Torres, A. L.: ECC ozonesonde performance at high altitudes: Pump efficiency, NASA Tech. Memo, TM 93290, 10 pp., 1981.

Waugh, W. W. and Polvani, L. M.: Climatology of Intrusions into the tropical upper troposphere, Geophys. Res. Lett., 23, 38573860, 2000. 